\title{
EXPERIMENTAL STUDIES OF OLIVINE LAMPROITE AT PRESSURES IN THE DIAMOND STABILITY FIELD
}

\author{
Foley, S.F. \\ Mineralogisch-Petrologisches Institut, Universität Göttingen, Goldschmidtstrass 1, 3400 Göttingen, Germany
}

At the last kimberlite conference, results of liquidus experiments at pressures up to a maximum of $40 \mathrm{kbar}$ on two lamproite compositions were presented (Foley, 1989a). The compositions studied were modelled on a leucite lamproite from Gaussberg, Antarctica, and an estimated primary magma composition for olivine lamproites from the West Kimberley lamproite field in Western Australia. The experiments on olivine lamproite are here extended to pressures up to $55 \mathrm{Kbar}$, and thus into the diamond stability field.

The new experiments were performed under the same volatile conditions as in the previous study, namely volatile saturated in the $\mathrm{C}-\mathrm{O}-\mathrm{H}$ system at oxygen fugacities one to two log units above the iron-wüstite buffer; the volatile phase consists principally of $\mathrm{H}_{2} \mathrm{O}>\mathrm{CH}_{4}$.

These volatile conditions were chosen to test the hypothesis that a range of lamproite primary magmas with $\mathrm{SiO}_{2}$ contents from 42 wto to about 53 wto could be derived from a single source assemblage (phlogopite harzburgite) under reducing conditions $\left(\mathrm{H}_{2} \mathrm{O}>\mathrm{CH}_{4}\right)$ by variation in the pressure of melting. In this scheme, the $\mathrm{SiO}_{2}$ contents of lamproites would be inversely proportional to their pressure of origin (Foley et al., 1986). The liquidus results up to $40 \mathrm{Kbar}$ were consistent with this model; leucite lamproite could be reconciled with a mica harzburgite source mineralogy at pressures of 15-20 Kbar if allowance was made for there being too much fluid in the experiments, whereas olivine lamproite had olivine at its liquidus up to $40 \mathrm{Kbar}$ as expected.

The higher pressure experiments were performed in a high temperaturecalibrated belt apparatus at the Max-Planck-Institut für Chemie in Mainz. Natural polycrystalline $\mathrm{CaF}_{2}$ was used as the pressure-transmitting medium, with pressure controlled automatically to within 300 bar. The results are depicted in Figure 1 , together with the lower pressure results from Foley (1989a). Olivine remains the only liquidus mineral to pressures above 50 Kbar, and is joined by mica and orthopyroxene and then ilmenite towards lower temperatures. At $55 \mathrm{Kbar}, 1300^{\circ} \mathrm{C} \mathrm{Ol,} \mathrm{Opx} \mathrm{and} \mathrm{Phl}$ coexist, whereas at 55 Kbar, $1350^{\circ} \mathrm{C}$ no primary crystalline phase is observed. This is consistent with the mica harzburgite melting model with a pressure of origin of 55 kbar for olivine lamproite. The olivine stability field has been extraploated to pressures greater than $55 \mathrm{Kbar}$ in Figure 1 since, as argued for leucite lamproite, the experiments contain an unrealistically large amount of fluid: this extra $\mathrm{H}_{2} \mathrm{O}$ has the effect of shrinking the ol phase volume, so that the true pressure of origin is more probably 60 Kar or slightly higher.

Partial melts of phlogopite harzburgite can be represented by the peritectic melting point $01+0 \mathrm{px}+\mathrm{Phl}+\mathrm{Lq}$ in the system kalsilite-forsteritequartz. This simple system also expresses the main variation in the major element chemistry of lamproites, which is in $\mathrm{K}_{2} \mathrm{O}, \mathrm{Al}_{2} \mathrm{O}_{3}, \mathrm{SiO}_{2}$ and $\mathrm{MgO}$. A combination of experimentally determined points for $\mathrm{H}_{2} \mathrm{O}$-saturated conditions ( 3 and 28 Kbar; Luth, 1967; Gupta and Green, 1988) and recast norms for leucite and olivine lamproite defines a trend representing the variation of composition of partial melts of phlogopite harzburgite with pressure (Figure 2). The low-pressure end of this trend lies at MgO-poor and thus $\mathrm{K}_{2} \mathrm{O}, \mathrm{Al}_{2} \mathrm{O}_{3}$ and $\mathrm{SiO}_{2}$-richer compositions. The most extreme natural examples are probably leucite lamproites from Spain and the Leucite Hills, USA, which may originate at depths of 10-15 Kbar. At the other extreme, olivine lamproites from Western Australia originate at $60 \mathrm{Kbar}$ or more. The persistence of olivine at subliquidus temperatures above $45 \mathrm{kbar}$ (not predicted by Foley, 1989a) can be explained by eutectic crystallization to the Fo-side of the opx-Phl join. 
conditions. Variation of $\mathrm{fO}_{2}$ in the volatile system $\mathrm{C}-\mathrm{O}-\mathrm{H}$ causes the melt composition to follow a trend transverse to the pressure trend. Only in the presence of $\mathrm{CO}_{2}$, and thus in more oxidizing conditions, will Sio,undersaturated melt compositions result. Such $\mathrm{CO}_{2}$-bearing conditions are not possible for the main lamproite series, but may apply to the rarer madupitic lamproites, which are characterized by higher CaO and lower $\mathrm{SiO}_{2}$ contents than most lamproites.

The origin of most lamproites in reduced conditions, where $\mathrm{CH}_{4}$ rather than $\mathrm{CO}_{2}$ is the main carbon species, is supported by the following lines of
evidence:

(i) Leucite cores in the Gaussberg lamproite have $\mathrm{Fe}^{3+}$ contents of $\sim 0.3$ wt\% corresponding to $\mathrm{fO}_{2} \ll(\mathrm{IW}+3)$. Rims and the main phenocryst population crystallized at marginally less than Ni-Nio (Foley, 1985). This indicates considerable near-surface oxidation of the lamproite magma.

(ii) Spinels included in lamproitic olivines indicate more reducing conditions than groundmass spinels using an experimental $\mathrm{fO}_{2}$ calibration (Foley, 1985).

(iii) Lamproites are typically rich in $\mathrm{H}_{2} \mathrm{O}$ and poor in $\mathrm{CO}_{2}$. The paucity of $\mathrm{C}$ is readily explained by its presence as $\mathrm{CH}_{4}$, which is much less soluble in silicate melts than $\mathrm{CO}_{2}$.

(iv) Partial melting of a mica harzburgite in which the mica has $\mathrm{K}_{2} \mathrm{O} / \mathrm{Al}_{2} \mathrm{O}_{3} \approx 1$ provides a convincing explanation for the extremely high $\mathrm{K}_{2} \mathrm{O} / \mathrm{Al}_{2} \mathrm{O}_{3} \mathrm{Of}$ lamproites. Such a mica can only crystallize in reduced conditions with $\mathrm{fO}_{2}$ close to IW (Foley, 1989b); more oxidized micas have $\mathrm{K}_{2} \mathrm{O} / \mathrm{Al}_{2} \mathrm{O}_{3}$
considerably less than 1.

(v) Lamproites from Smoky Butte, USA, have micas which possess these same "reduced" characteristics, and also contain armalcolite phenocrysts which indicate $\mathrm{fO}_{2} \approx I W$ to IW+2 log units (Friel et al., 1977).

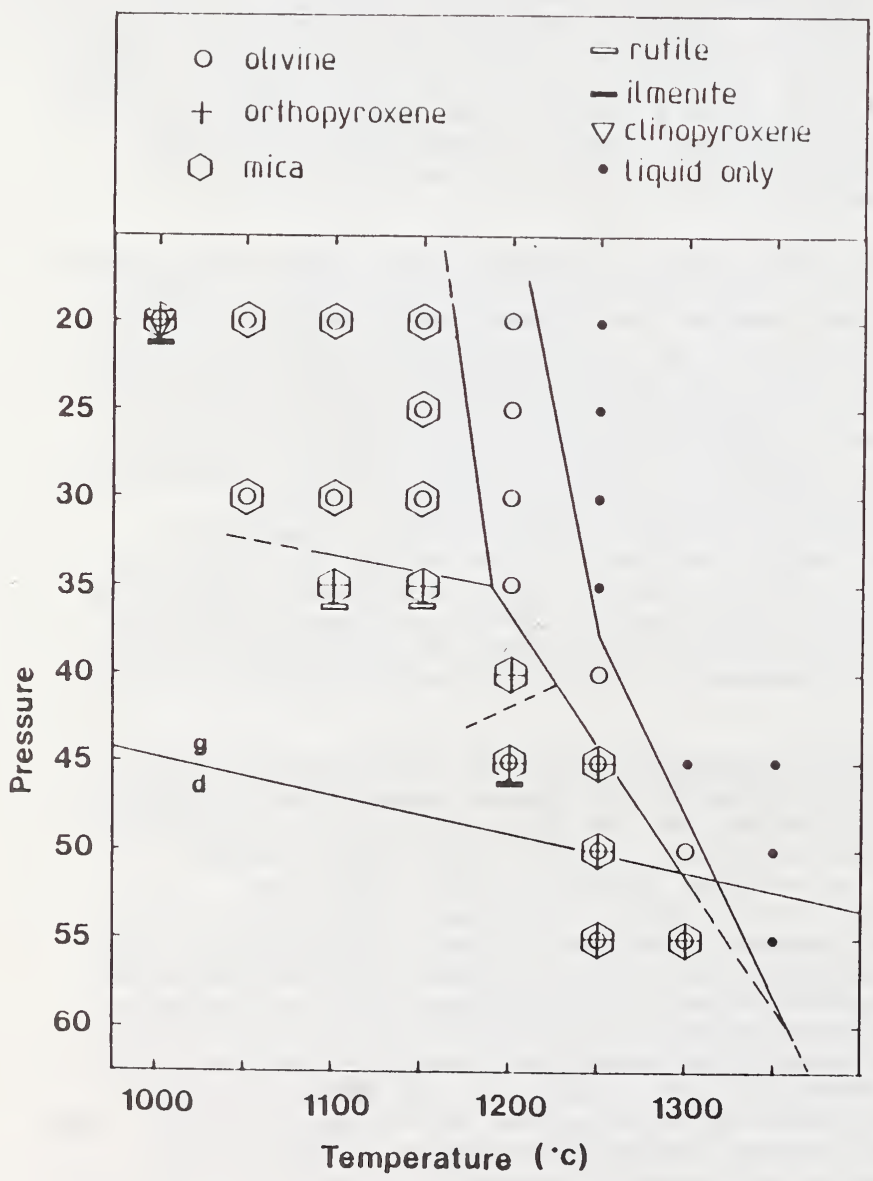

\section{Figure 1}

Experimental results for liquidus experiments on olivine lamproite. 


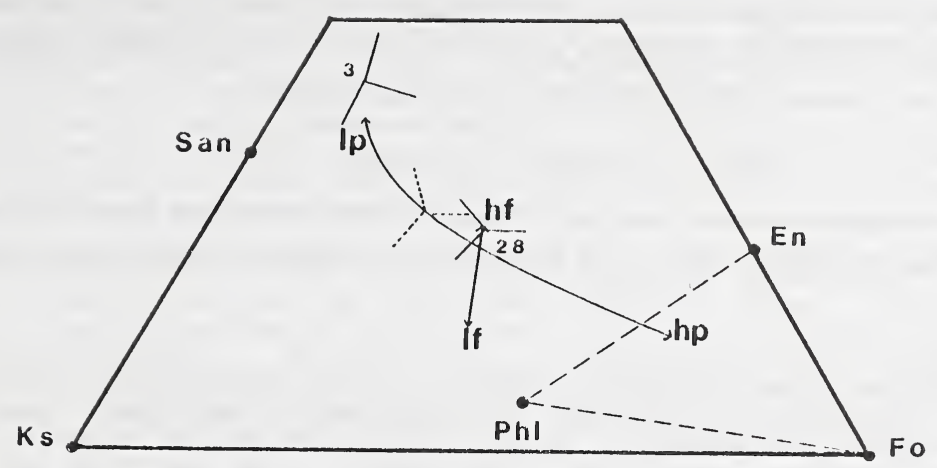

In addition to the liquidus study on the estimated primary olivine lamproite composition, a few experiments have been conducted using a natural olivine lamproite from dyke sample BMR 8321-1034 (kindly supplied by Lynton Jaques). This lamproite has a composition similar to the estimated primary magma, but with lower $\mathrm{K}_{2} \mathrm{O}$ ( 3.4 wto) and $\mathrm{Na}_{2} \mathrm{O}$ contents $(0.15 \mathrm{wt} \%)$ : details of chemistry and petrography for this sample are given by Jaques et al. (1989).

The composition has been modified slightly by the addition of $\mathrm{TiO}_{2}$, increasing the content from 3.44 to 5 wto. These experiments form part of another experimental program aimed principally at studying $\mathrm{TiO}_{2}$ solubilities in mantle-derived magmas, and the possible role of titanate minerals in their sources. However, mention of them is relevant. here because they include several runs at temperatures considerably below the liquidus. The experiments were conducted in the coH-fluid system using graphite capsules and a Co-CoO buffer mixture. This buffer defines the composition of the fluid phase as extremely $\mathrm{H}_{2} \mathrm{O}-\mathrm{rich}(>99.5 \mathrm{~mol} \%$ - measured by mass spectrometer) at high pressures and relatively low temperatures. The $\mathrm{fO}_{2}$ lies slightly above that defined by the CWI technique used for the other lamproite experiments. Use of this buffer has not yet been perfected, so that some of the experiments were not fluid-saturated; the $\mathrm{fO}_{2}$ should nevertheless be very close to the Co-Coo buffer.

At subliquidus temperatures in the Argyle experiments, clinopyroxene appears at much higer temperatures than garnet. At $35 \mathrm{Kbar}$, $\mathrm{Cpx}$ is present in a run at $1200^{\circ} \mathrm{C}$ (together with Opx, Phl + Rut), whereas garnet is not present at $1050^{\circ} \mathrm{C}(\mathrm{Cpx}, \mathrm{Opx}, \mathrm{Phl}+$ Rut present). Garnet is present at 43 Kbar, $1020^{\circ} \mathrm{C}$ in a run which also contains Opx, Cpx, Phl, rutile and apatite. The $\mathrm{Cpx}$ has $\mathrm{Mg}$-number of 89 , and low $\mathrm{Al}_{2} \mathrm{O}_{3}$ contents $(0.5-0.9$ wt\%). Garnet has much lower Mg-number $(\approx 70)$, and has low CaO (5.8-7.4 wt\%) and high Mno (0.6-0.9 wt\%) contents. Rutile shows similar characteristics to those analysed previously in lamproite experiments, with high $\mathrm{Fe}$ and $\mathrm{Cr}$.

Since the phase volume of $\mathrm{Cpx}$ expands greatly with a small increase in $\mathrm{fO}_{2}$ ( $\mathrm{i} . \mathrm{e}$. With $\mathrm{CO}_{2}$ present), madupitic lamproites leaving $\mathrm{Cpx}$ stable in the residuum could be generated from a similar source to other lamproites where slightly higher $\mathrm{fO}_{2}$ prevails.

Foley, S.F. (1985) Tschermaks Min. Petr. Mitt. 34, 217-238

Foley, S.F. (1989a) In: Kimberlites and related rocks I (eds. A.L.Jaques, J.Ferguson and D.H.Green) 616-632, Blackwells, Melbourne.

Foley, S.F. (1989b) Eur. J. Mineral. 1, 411-426

Foley, S.F., Taylor, W.R. and Green, D.H. (1986) Contrib. Mineral. Petrol. $93,46-55$

Friel, J.J., Harker, R.I and Ulmer, G.C. (1977) Geochim. Cosmochim. Acta $41,403-410$

Gupta, A.K. and Green, D.H. (1988) Mineral. Petrol. 39, 163-174

Jaques, A.L., Sun, S-S. and Chappell, B.W. (1989) In: Kimberlites and related rocks I (eds. A.L.Jaques, J.Ferguson and D.H.Green) 170-188, Blackwells, Melbourne.

Luth, W.C. (1967) J.Petrol. 8, 372-416 